\title{
INTERNATIONAL LEGAL SETTLEMENT OF THE CONFLICTS AS THE FACTOR IN GLOBAL SECURITY THREATS COUNTERMEASURES
}

\author{
Muradova Vusala Khagani gizi \\ PhD student at the Institute of Law and Human Rights \\ National Academy of Sciences of Azerbaijan, \\ Baku, Republic of Azerbayjan
}

\begin{abstract}
SUMMARY
The article "International legal settlement of the conflicts as the factor in global security threats countermeasures" examines the influence of the growing dynamics of conflicts, the precedents of the internationalization of local-regional conflicts on international legal relations. The author proves that the international legal settlement of conflicts in a globalization environment is undergoing complex changes related to the creation of the doctrine of "new generation conflicts" and the formation of new generation law branches - security law, sustainable development law, migration law, etc. Application to international and regional conflicts of the guarantees agreed by international law is the only possible way to settle them.

KEY WORDS: global security, threats, international legal settlement, new generation conflicts, armed conflict, human rights, intersectoral convergence.
\end{abstract}

\section{DISCUSSION}

Formally and legally, almost by initial stage of the globalization, international law reached a high level of development due to the putting forward the concept of the supremacy of law, the prohibition of the use of force and the threat of force by UN Charter. Despite the ever-increasing volume of international legal acts restricting the use of force over the past twenty years, as Global Security Strategy of the European Union postulates, "no region of the world has escaped armed conflict. The results of regional conflicts are not limited to areas geographically close to the EU and are global in nature." The fragmentation of the entire architecture of collective security at global level due to the growing of regional conflicts and the accompanying fragmentation of international law allows accepting the conflicts as main global security threat, relegating anthropogenic threats to the background.

Globalization processes activate the pluralization of new actors in the world politics and, accordingly, involve new relations in international legal settlement. The phenomenon of global problems lies in the fact that it requires not only the universal participation of all states in threats and challenges countermeasures, but also regional-local international legal settlement of the conflicts. Despite the practical completion of the ethnopolitical redistribution caused by the fall of the USSR and the fall of socialist block, the growing dynamics of local-regional conflict complicated international legal relations, and the number of armed stand-off involving the countries increased significantly.

In comparison with most conflicts of the $70 \mathrm{~s}$ and 80 s that were ideological, in modern globalization conditions, as stated by the UN General Assembly Resolution A/70/PV.117, UN GA (2016), the conflicts all-around the control over governing bodies dominate, all-around natural and economic resources, which are superimposed ethnic polarization, socio-economic tension. Mentioned factors form the precedents for the internationalization of local-regional conflicts (11). 
Regional conflicts are characterized by the increasing of the opportunities for the use of tactical nuclear weapons got through transnational organized crime channels and terrorist networks. In epy Resolution 1540 (2004), the UN Security Council gave international peace and security threat status to the proliferation and falling of weapons of mass destruction into the hands of non-governmental subjects. Regional conflicts are very likely to develop into global ones, as they create motivation for the acquisition of all types of WMD (tactical nuclear, chemical, biological), the use of which is able to become the cause not only of large-scale, often irreversible destruction (12). In the ongoing Syrian conflict, the UN Security Council Commission on the Investigation of Human Rights Crimes in Syria within the period from 2011 to 2017 reported more than twenty cases of the use of chemical weapons. However, since there are several warring parties in this regional conflict, both state and non-governmental, it is impossible to establish the subject of international responsibility (11)

The threat is not only tactical nuclear weapons, but also the humanitarian results of the conflicts: the growth of participants in unregulated conflicts, increase of the number of refugees and internally displaced persons, environmental disasters. At the $72^{\text {nd }}$ session of the General Assembly (2018), the UN Secretary-General noted that the number of the countries affected by regional violent conflicts in recent years is more than in any period over the past three decades (1).

International and regional conflicts constitute challenges to legal provision of global security for the following reasons: unregulated conflicts produce a crisis of the supremacy of law; existing international law enforcement is being destroyed. In order to counter threats arisen by regional conflicts, "international community is compelled to use innovative approaches, departing from classical international legal principles" (7.p.159).

The UN Charter does not contain the concept of "conflict", and this, of course, does not provide the conflict settlement mechanisms. However, Art. 34 of the UN Charter determines the competence of the UN Security Council to consider any dispute or any situation that could lead to international tension. In many international legal acts, the conflict settlement is defined as the means of the maintaining of global security. In particular, in UN Security Council resolution 1377 (2001) "On global efforts on the counterterrorism", regional conflicts settlement is qualified as global task, the solution of which will contribute to the security of all mankind (12).

International Law Commission at the $53^{\text {rd }} \mathrm{GA}$ session in 2001 determined "fundamental conceptual shift that takes place in international law now and which is expressed in the transition from individualism to a certain form of collectivism when it comes to ensuring compliance and more effective consolidation of international law in peace dispute settlement."(3).
International legal settlement of conflicts in modern globalization conditions undergoes complex changes in accordance with the formation of the doctrine of "new generation conflicts". The new doctrine of international law, according to the German professor of law H.J. Heintz, is based on the convergence of international humanitarian law and international human rights law caused by the growth of conflicts (14).

The specificity of modern armed conflicts as global security system threat is manifested in the erosion of the traditional differences between international and internal armed conflicts. The latter, as accepted by International Law Commission, are statistically more frequent. (4). Over the past two decades, in the experience of the Security Council and in the reports of some of its special rapporteurs, recommendations have been made to call on an armed group that is a non-government subject and has no legal capacity to formally assume international obligations to respect international human rights standards.

Real possibilities of the considerable control implemented by it over the territory and population, as well the presence of a certain political structure is criterion for referring to such a group. In newgeneration conflicts, international human rights law takes precedence "as a lex specialis in that region on the territory of the state whose government is fighting against the rebel forces. This region, significant in the scale of this country, is confidently not controlled by either the rebels or the government. "(16.p.39.). Conceptual shift in the conflict settlement in the context of the globalization is based on the acceptance of the concept of intersectoral convergence in legal settlement of the conflicts as an essential part of modern international legal doctrine of "new generation" conflicts.

As follows from the "new generation" conflict doctrine, national sovereignty is relegated to the background because it is in a subordinate position in relation to universal rights. Thus, "new generation" conflicts develop in two international legal regimes, "when the concept of sovereignty as the highest value is no longer dominant, and the universalist approach to human rights is not yet dominant" (9.p.12.).

It seems to us that, conceptual shift of international law in the settlement of international conflicts, due to the growth of globalization threats, is not limited only to intersectoral convergence. The dynamics and directions of the conceptual shift under study are also associated with: the formation of new generation law fields - security law, sustainable development law, migration law, etc.; international legal settlement of the use of force; expansion of protection objects; the development of international legal ground for the cooperation between the UN and international regional organizations, the expansion of their areas of interaction; the application by states of universal criminal jurisdiction over massive and gross violations of human rights; recognition of international 
criminal jurisdiction not only in relation to individuals personifying the responsibility of their states for the commission of international crimes, "but also in relation to persons who commit crimes of an international nature without acting on behalf of any state" (8. p.296).

Under globalization conditions, it is becoming increasingly difficult to regulate conflicts by international legal means, due to: fragmentation of international law, the multiplicity of international judicial bodies (13.p. 101), insufficient development of international legal norms related to international legal settlement of large non-governmental and transnational formal and informal structures , in particular, "private military companies and non-governmental "humanitarian" political corporations" (10. p.99); putting forward, as arguments, not international legal norms, but political factors, which often influence the decision-making process of international organizations.

As imperative norm, the principle of peaceful settlement of disputes and conflicts obliges all the subjects of international law to regulate all the arisen contradictions without the use of force. It should be noted that the word "war" is not used in the UN Charter in the sense of a legal concept. As such, in paragraph 4 of Art. 2 of the UN Charter, the concept of "force" is used. It should be noted that the provisions of paragraph 4 of Art. 2 of the UN Charter was interpreted in the Declaration on the Principles of International Law. The UN Charter also does not contain the concept of "conflict", which, of course, does not provide for conflict settlement mechanisms. However, Art. 34 of the UN Charter defines the powers of the UN Security Council to consider any dispute or any situation that could lead to international tension. None of the Secretary-General's annual reports on the work of the UN has been contained the sections on the peaceful settlement of international disputes since 1998, but defines new international legal agenda for conflict management, including conflict prevention, peacekeeping and post-conflict peacebuilding.

Up to date, doctrinal views and concepts of the current state of international law have been formed in the assessment of Chapter VII of the UN Charter, "Actions Relating to the Peace Threats, Violations of the Peace and Acts of Aggression." These doctrines accept convergence as a process of interaction and rapprochement of elements of the mechanism of legal settlement of branches of international law as a necessary comprehensive normative regulator of global security (5.p. 72; 6.p. 8; 10.p. 99; 17). International Law Commission at the $68^{\text {th }}$ session (2016) recommended that $\mathrm{UN}$ member states and regional organizations submit their disputes to a political forum to settle them through multilateral political influence and procedures, such as fact-finding missions, to use extra-judicial methods, such as mediation, reconciliation and investigation.

Insufficiently developed regulatory framework for the settlement of international conflicts is actual problem of ensuring global security. Related to it, it should be noted that, the more precisely and more detailed the legal settlement norm is developed, the more effective is the mechanism for its application. The stability of the concept of jus cogens norms, which is the foundation of the system of international law, suggests that the jus cogens norm applies to the principle of the peaceful settlement of international disputes. All the articles of Chapter VI of the UN Charter "Peaceful Settlement of Disputes" reveal legal nature of the settlement of the relations, the development of which threatens the maintenance of international peace and security. The application to regional conflicts of the guarantees agreed by international law is the only possible way to resolve them. Peaceful settlement of international contradictions and disputes based on the justice, in accordance with paragraph 1 of Art. 1 of the UN Charter, is one of the types of international legal guarantees that can support the global security regime.

UN Security Council Resolution No. 748 (March 1992) affirmed the primacy of states' obligations under Article 103 of the UN Charter over states' obligations arising from other international agreements. The UN International Court, in its decision on the Lockberry Case, confirmed the application of this article to the obligations of states arising from Security Council resolutions in 1992. (15) The legal basis for the application of peaceful means of settlement of international conflicts should be based on a triunity of norms of international law, including norms of legal settlement, norms of obligations of subjects and norms of legal settlement means. The fundamental role of the norms and principles of the UN Charter in legal settlement of international contradictions is an instrument of exceptional importance, exceeding the strength of another international agreement. International legal unity in relation to disputes and situations, laid by the UN Charter as a source of international law, creates the basis for the peaceful legal settlement of conflicts that threaten global security.

\section{REFERENCES}

1. General Assembly The seventy-second session Paragraph 65 Peacebuilding and peacekeeping A/72/707S/2018/43. 18 January 2018 www.un.org/.../SG\%20report\%20on\%20peacebuildin $g \% 2$

2. EU Global Strategy for International Policy and Security Policy. 2016. https://eeas.europa.eu/sites/eeas/

3. Report of the International Law Commission on its fiftythird session activity (23 April - 1 June and 2 July -10 August 2001). Document A/56/10: $A \backslash C N / 4 \backslash S R$. http://legal.un.org/ilc/publications/yearbooks/

4. Report of the International Law Commission The sixtieth session (5 May - 6 June and 7 July - 8 August 2008) General Assembly Official reports. The sixty third session. Annex № 10 (A/63/10).: http:/www.un.org/ru/ /pdf/armed_conflicts 
5. Zverev P.G. - Definitions of armed conflict in international law // Legal research. - 2015. - № 5. P. $69-103$.

6. Klochkova Y.A. Convergence Legal Systems as a Result of Modern Globalization // State power and local governance. 2001. № 4. P. 6-10.

7. Lobanov S.A. International criminal responsibility for war crimes. Dissertation of M. 2018.

8. International law / Associate editor Y.M.Kolosov, E.S.Krivchikova. M.: International relations, 2001.

9. Mesheryakova O.M. Supranationalism in European Union Law and the Problem of Sovereignty. Dissertation of M., 2010.

10. Ovada Kh. The Impact of Human Rights Law on International Law: Borrowing from Specific Concepts or Revising of the Fundamentals? Modern international law: Local and foreign research. M: RAN.INION.2016

11. UN General Assembly Resolution A/70/PV.117, Strengthening of the role of mediation in the peaceful legal settlement of disputes, conflict prevention and $\begin{array}{llll}\text { settlement. } & 9 & \text { September } & 2016 .\end{array}$ http://unctad.org/meetings.

12. UN Security Council Resolution. On global counterterrorism efforts. https://documents-ddsny.un.org/doc/UNDOC/GEN/NO1/633/03/

13. Tunkin G. International law theory. M.:Zertsalo, 2006

14. Hans-Hoahim Heintze. On the relationship between human rights protection and international humanitarian law //JCRC. December 2004. Vol. 86. № 856.http://www.un.org/ru/documents/decl_conv/con ventions/armed_conflict

15. ICJ. Order With Regard To Request For the Indication of Provisiponal Measures In The Case Concerning Questions of Interpretation and Application of the 1971 Montreal Convention Arising From The Aerial Incident at Lockerbie (Libya v. United States), Apr. 14, 1992, 31 LL.M. 662, 665-666. https: //www.icj-cij.org/en/case/88

16. International Law: Theory and Practice - Essays in Honour of Eric Suy / ed. K. Wellens. - London: Martinus Nijhoff, 1998. - 809

17. Geoff Gilbert and Clara Sandoval. Cross-border conflict and international law.www.c-r.org/accord-article/crossborder-conflict-and-international-law 